\title{
Фармакогенетический подход в осуществлении выбора нестероидного противовоспалительного препарата у пациентки с синдромом хронической тазовой боли
}

\author{
Мамина Р. М. \\ ФГБОУ ВО «Астраханский государственный медицинский университет» Министерства здравоохранения \\ Российской Федерации, Россия, Астрахань
}

Ключевые слова: генотипирование; фармакогенетическое тестирование; НПВП; синдром хронической тазовой боли; персонализация терапии

Для цитирования:

Мамина Р.М. Фармакогенетический подход в осуществлении выбора нестероидного противовоспалительного препарата у пациентки с синдромом хронической тазовой боли // Фармакогенетика и фармакогеномика. 2020;(2):36-37. (In Russ). DOI: 10.37489/2588-0527-2020-2-36-37

Описание пациента. Больная К., 49 лет, находилась в неврологическом отделении частного учреждения здравоохранения «Медико-санитарная часть», г. Астрахани с 22.02.2018 по 05.05.2018 гг. с диагнозом: синдром хронической тазовой боли (СХТБ). Двустороння люмбоишиалгия с выраженным болевым и мышечно-тоническим синдромами. Остеохондроз пояснично-крестцового отдела позвоночника. Деформирующий спондилез (22.02.2018 г.).

При поступлении предъявляла жалобы на выраженные стойкие боли в области таза и скованность в пояснично-крестцовом отделе позвоночника с иррадиацией по заднебоковой поверхности обеих ног, усиливающиеся при движении, осевой и статической нагрузке; снижение качества жизни и нарушение сна из-за выраженного болевого синдрома.

Из анамнеза заболевания известно, что впервые боли в области таза появились несколько лет назад. Неоднократно получала стационарное лечение в неврологическом отделении ЧУЗ МСЧ г. Астрахани. Кроме того, неоднократно лечилась амбулаторно. Получала таблетированные нестероидные противовоспалительные препараты (найзилат, диклофенак, ибупрофен), также использовала НПВП-содержащие мази. Курс применения НПВП был коротким, ввиду появления на фоне их приёма тошноты, рвоты, изжоги, болезненных ощущений в гастродуоденальной области, что заставляло пациентку самостоятельно прекращать приём НПВП через 2-3 дня от начала амбулаторного лечения. Со слов больной, приём омепразола в дозе 20 мг в сутки, однократно утром, не обеспечивал предупреждение появления НПР со стороны ЖКТ. Болевой синдром при этом не купировался.
В течение последних нескольких дней интенсивность болей усилилась, нарушился сон, в связи с чем пациентка обратилась в ЧУЗ МСЧ г. Астрахани для получения стационарного лечения.

Из анамнеза жизни известно, что страдает хроническим эрозивным гастродуоденитом, с обострениями 2-3 раза в год; желчекаменной болезнью.

Краткая клиническая характеристика пациента. Общее состояние неудовлетворительное. В сознании, контактна, на вопросы отвечает правильно.

Кожные покровы и слизистые обычной окраски. Периферические лимфатические узлы не пальпируются. Гиперстенический конституциальный тип.

Походка анталгическая, положение тела щадящее. В позе Ромберга устойчива. Анталгический сколиоз. Пальпация паравертебральных точек в пояснично-крестцовом отделе позвоночника резко болезненна. Выраженный дефанс мышц спины в проекции пояснично-крестцового отдела, с двух сторон. Синдром Нери положительный. Синдром Ласега справа 40 градусов, слева 35 градусов. Движения в пояснично-крестцовом отделе ограничены при наклонах вперед и назад, резко болезненны. Интенсивность боли по визуально-аналоговой шкале (ВАШ) 9 баллов.

Щитовидная железа не увеличена. При пальпации безболезненна.

Грудная клетка правильной формы. Перкуторно над всей поверхностью лёгких определяется лёгочный звук. Аускультативно - дыхание везикулярное, хрипов нет. ЧДД - 18 в минуту.

Область сердца визуально не изменена. Границы относительной сердечной тупости: правая по правому краю грудины, верхняя -3 ребро; левая - 
по левой среднеключичной линии. Тоны сердца умеренно приглушены. Ритм сердца правильный, частота сердечных сокращений - 75 в минуту. АД 120/80 мм. рт.ст.

Живот мягкий, при пальпации в гастродуоденальной зоне безболезненный. Печень не пальпируется. Перкуторно нижний край печени по краю правой реберной дуги.

Отёков нет. Мочеиспускание свободное, безболезненное.

Тип вмешательства. До персонализации терапии пациентка стационарно и амбулаторно получала НПВП без учёта данных результатов исследования на носительство полиморфных аллелей гена СҮР2С9, участвующего в метаболизме НПВП. Назначение НПВП данной больной было сопряжено с развитием НПР, что ограничивало возможности применения препаратов этой группы. Миорелаксанты центрального действия (мидокалм), в сочетании с физиотерапевтическим воздействием (интерференцтерапией) давали временный эффект и не обеспечивали стойкой ремиссии.

Показания к персонализации. Показанием к персонализации терапии послужила необходимость длительного обезболивания с применением НПВП у пациентки с СХТБ, на фоне частых эпизодов развития НПР в анамнезе заболевания и сопутствующей коморбидной патологии в виде эрозивного гастродуоденита.
Тип персонализации. Генотипирование образца крови пациентки, для определения возможного носительства полиморфных аллелей гена CYP2C9.

Изменения после персонализации. Пациентка оказалась носителем медленной (РМ) аллели СҮР2C9*3. В связи с чем, было принято решение о назначении ацеклофенака (аэртала), не являющегося субстратом изофермента цитохрома Р-450 CYP2C9. Препарат назначался в средне терапевтической дозе 100 мг/сут, в соответствии с российскими клиническими рекомендациями «Рациональное применение нестероидных противовоспалительных препаратов НПВП в клинической практике» и инструкциями государственного реестра лекарственных средств.

Динамика. На фоне применения ацеклофенака, подобранного по результатам генетического тестирования, отмечалась хорошая переносимость препарата. Состояние больной к 7-му дню стационарного лечения заметно улучшилось, интенсивность боли уменьшилась (9 баллов vs 5 баллов по ВАШ). Нормализовалось общее состояние и сон, улучшилось качество жизни. На фоне проводимого лечения проявления НПР не отмечались.

Заключение. В данном клиническом случае технологии персонализированной терапии позволили индивидуально подобрать пациентке наиболее рациональный, эффективный и безопасный НПВП для лечения болевого синдрома. 